\title{
一般 12
}

\section{地域住民における尿酸代謝関連遺伝子多型と 生命予後の関連について：山形(高畠)研究}

亀井 啓太 今田 恒夫 鈴木 和子

目 的

尿酸代謝は, 食事生活習慣とともに遺伝素因の 影響を強く受けており, 高尿酸血症は腎・血管障 害を介し, 心血管疾患, 末期腎不全, 生命予後と 関連することが報告されている，本研究では，地 域住民コホートにおける尿酸代謝に関連する遺伝 子の一塩基多型（SNPs）と生命予後の関連につ いて前向きに検討した。

\section{方 法}

対象は2004年に山形県高畠町の地域健康診断 を受診した 1599 名（男性 44\%, 平均年齢 61 歳). 7 年間（中央值 6.7 年）追跡し, 尿酸代謝関連 4 遺 伝子（URAT1, ABCG2, GLUT9, UMOD）の一塩 基多型と生命予後の関連について, 背景因子を補 正して検討した.

\section{結 果}

追跡期間中の総死亡は 51 名 $(3.2 \%)$, そのうち心 血管死亡は 10 名 $(0.6 \%)$ であった．年齢・性別で補 正した総死亡リスクでは, UMOD遺伝子多型 (rs4293393:GG+GA vs AA) が有意な関連を認めた が, URAT1 (rs505802:GG vs AG+AA), ABCG2 (rs2231142:AC+CC vs AA)，GLUT9（rs16890979:AG vs GG）遺伝子多型との関連は有意ではなかった。
しかし，併存症・生活習慣などの背景因子（高血 圧, 糖尿病, 肥満, 飲酒, 喫煙, 腎機能, 脂質異常, 蛋白尿）も補正因子に加えたところ, UMOD, URAT1，ABCG2の遺伝子多型は，総死亡とそれ ぞれ独立した関連を示した。ささらに血清尿酸值も 交絡因子として含めた解析では，これら 3 遺伝子 の多型と総死亡の有意な関連は保たれ，血清尿酸 值自体は有意な関連を示さなかった。

\section{考 察}

本検討では, URAT1, ABCG2, UMODの一塩基 多型は，交絡因子で補正すると，追跡期間の総死 亡と有意な関連を示したことから，尿酸代謝に関 連する遺伝素因は, 既知のリスク因子とは独立し て, 生命予後の予測因子となることが示唆された。 血清尿酸值で補正してもこの関連は保たれたこと から，血中尿酸レベルの調節以外の機序が関与す る可能性が示されたが, その詳細な機序は不明で ある。

\section{結 論}

本検討結果から，日本人地域住民において，尿 酸代謝に関連する遺伝子群の一塩基多型は, 血清 尿酸值とは独立した生命予後の予測因子となる可 能性が示された。 